\title{
The Precariousness Employment in the Eurasian Economic Space: Measurement Problems, Factors and Main Forms of Development*
}

\author{
Saule A. Kaliyeva ${ }^{1}$, Farida G. Alzhanova ${ }^{2}$, Marziya K. Meldakhanova ${ }^{3}$, \\ Ilyas M. Sadykov ${ }^{4}$, Murat A. Adilkhanov ${ }^{5}$ \\ Received: May 30, 2018 Revised: June 30, 2018 Accepted: July 30, 2018
}

\begin{abstract}
This research aims to generalize the conceptual basis of precariousness of employment, study the factors and scale of unsustainable of employment in the countries of the Eurasian Economic Union (EAEU). The concept of precariousness of employment is formed in social and economic studies about 40 years ago, but objective and subjective conditions and forms of unsustainable employment existed before. This study proposes a classification of forms of precariousness of employment on 16 criteria: the duration and timing of agreements, contract terms, the nature of income; the degree of labor autonomy; the level of formality; the level of openness; the level of vulnerability; the conditions of growth of qualification; the level of flexibility; the level of stability; regularity; the severity of the danger of work; in relation to the workplace; the quality of employment, the level of social security. In this research highlighted factors (globalization, demography, migration, structure factors, shadow and informal economy, social development and living standards, unemployment), and systematized certain trends of precariousness of employment, channels and means, forms of manifestation. The empirical analysis identified of the labor potential of the Eurasian countries and new quantitative estimates of the levels of unsustainable employment in the Eurasian Economic Space.
\end{abstract}

Keywords: Employment, Vulnerable Employment, Informal Employment, Eurasian Economic Union, Kazakhstan.

JEL Classification Code: J01, J08, J21, J28, J46.

* The paper was presented initially at 2018 International Conference on Business and Economics (ICBE2018) and the 14th International Conference of KODISA that was held in Seoul, South Korea, June 25-27, 2018. The paper has been recognized as one of Best Paper Awards at ICBE2018 conference. This paper is a substantially revised and expanded version of the paper presented at ICBE2018 conference. The authors have taken into account all the comments of Editors, Session Chairs and Reviewers in the revised manuscript. The authors greatly appreciate Editors, Session Chairs and Reviewers for their valuable comments, interest in and support of this research.

1 First Author. Chief Researcher, Institute of Economics of the Ministry of Education and Science; Professor, Al-Farabi KazNU, Almaty, Kazakhstan E-mail: Kalievas@mail.ru

2 Corresponding Author. Head of Department, Institute of Economics of the Ministry of Education and Science; Professor, Al-Farabi KazNU, Almaty, Kazakhstan [Postal Address: 29 Kurmangazy Street, Almaty 050010, Kazakhstan]

E-mail: farida.alzhanova@gmail.com

3 Chief Researcher. Institute of Economics of the Ministry of Education and Science of the Republic of Kazakhstan. Almaty, Kazakhstan E-mail: Marziya_@mail.ru

\section{Introduction}

In scientific research in the field of social and labor relations, one of the most pressing is the problem of precarious of employment. The reduction of standard labor relations, including due to the digitalization, the emergence of non-standard, non-guaranteed and unprotected forms of employment (temporary employment, part-time employment, multilateral labor relations, self-employment, remote employment, mobile workplace, flexible schedule, fixed-term employment contract) becomes a challenge for the institutions of the labor market and social policy (ILO, 2016). The phenomenon of precariousness of employment is widespread in the Eurasian economic space. This phenomenon is due the increased unemployment, the liberalization of markets, deregulation of labor relations, the

$4 \mathrm{PhD}$ Researcher. Institute of Economics of the Ministry of Education and Science of the Republic of Kazakhstan. Almaty, Kazakhstan E-mail: ilyas.sadykov@mail.ru

5 Candidate of Economic Science. Koktem Group Ltd., Almaty, Kazakhstan E-mail: murat.adilkhan@gmail.com 
reduction of social security, labor migration, the large size of the non-observed economy and self-employment, informal employment and increasing inequality. The precariousness employment carries with it great social risks and consequences in the form of increased social vulnerability of workers, reduction of social guarantees and social protection.

The precariousness employment has an extremely wide range of forms and types. Due to the multidimensionality of precarious, the assessment of the scope risks and consequences of precariousness remains a serious research problem. The purpose of this research is to generalize the conceptual basis of unsustainable employment, study the factors and scale of precariousness of employment in the EAEU countries.

\section{Literature Review}

The concept of precarious of employment formed in social and economic studies about 40 years ago. At the same time, it is obvious that aim and subjective conditions and forms of unsustainable employment considered in the classical political economy. For example, Adam Smith described in "The Wealth of Nations" in 1776 the problems of inequality in labor and unsustainable employment. He identified five main conditions for wage differentials. According to him, wages are due, firstly, "the ease or difficulty, cleanliness or untidiness, honor or humiliation of the work", i.e. he highlighted the problem of profession and employment. Thirdly, by the persistence or interruption in work. "In some industries, the employee is confident that he will have a job all year round, while in others the workers have an unstable work depending on the season, weather, and random orders of their customers". Here we are talking about flexibility of employment. Fourthly, from the level of confidence in the employee. The new scientific research about precarious point out such features as minimal trust relationships with capital or the state. Fifthly, the probability of success in the profession - "high for mechanical training (e.g. shoemaker), low in liberal professions (e.g. lawyer)" (Smith, 2007).

Karl Marx in his work "Capital" in 1867 noted that the labor force could appear on "the market as a product only when it is offered by the free owner of his ability to work for a certain period" (Marx, 2001, p.154). Thus, the limitation of time for the use of the labor force is an inherent feature of the labor market and wage employment. Marx considered such forms of precariousness employment as forced labor migration and employment at home. He noted that domestic work enhances the irregularity of employment, exploitation becomes stronger, workers' ability to resist decreases, and poverty negatively affects working conditions accommodation, light, ventilation, etc. (Marx, 2001).

At the beginning of the 20th century J.M. Keynes in his book "General Theory of Employment, Interest and Money" introduced the concept of "forced unemployment" (Keynes, 2010). Forced unemployment creates conditions, in which a person is willing to accept less attractive working conditions or greater intensity of work. It is correspond to modern ideas about precariousness. Workers who take temporary jobs after a period of unemployment generally have lower incomes and less long-term jobs (Autor \& Houseman, 2010). It should be noted that the new forms of flexible, nonstandard employment with the spread in economic policy ideas neoliberalism, natural unemployment rate (Friedman, 1978), flexible of employment (Atkinson, 1984) are formed. These forms include self-employment, fixed-term employment contracts, part-time employment, out staffing contracts, combining different types of work, employment outside the location of the employer, etc.

Precariousness (as opposed to sustainability) is considered in new scientific studies with different social and economic aspects. Thus, Pierre Bourdieu notes that precariousness are not only cover the sphere of labor, but they isolated the individual, leads to a state close to the conditions of unemployment or exclusion from society (Bourdieu, 1998). Similar ideas expressed also (Sennet, 2006). They highlighted social, existential, professional, economic precariousness, focusing on the risks of destruction of human resources and social instability. Guy Standing, links precariousness with the institutionalization of neoliberalism in public policy, which is expressed in increasing the flexibility and openness of markets (Standing, 2011). Standing, as many other authors, notes that precariousness affects people who do not have permanent employment, legal guarantees in the field of labor relations and the appropriate education. Among the main social groups potentially exposed to precariousness, Standing includes youth, women and the elderly. The European Commission defines vulnerable employment as the combination of a low level of confidence in the continuity of the work, poor individual control over work (especially working time), the low level of protection (against unemployment or discrimination) and low opportunities for training and career development (EU, 2013).

The international labor organization considers four main types of non-standard forms of employment: temporary employment, part-time employment, multilateral labor relations, and dependent self-employment. In some cases, non-standard employment becomes an informed choice and has positive results. However, for most workers, nonstandard employment is related to insecurity (ILO, 2016). In recent years, the problems of precarious have investigated 
in Eurasian countries (Jumambayev, 2016; Gasyukova, 2015; Bobkov, Novikova, \& Odintsova, 2017). They connect the precariousness employment with the fact that the labor market is becoming increasingly diverse in all modern economies.

The literature review allows us to formulate the following definitions, which is based on to evaluate and measure of precariousness. The precariousness employment is a form of self-employment (or wage employment of individuals) based on employment contracts (or informal agreements) with the employer, which is to characterize by the absence or limitation of the rights of the employee in the workplace, access to social protection mechanisms, guarantees, in obtaining a stable employment and income, in preserving the qualification, professional status and ensuring decent work. The precariousness employment is a process of increasing volatility in employment and using precarious forms of employment in the labor market. The definition "precariousness of employment" relates with forms of employment or precarious, unstable, precursory type of work. The precariousness employment is a concept that is relevant to the process of increasing the volatility of the labor force in the labor market.

\section{Research Methodology}

The precariousness employment is a multidimensional phenomenon that takes different forms and is assessed through a variety of methods. The methodology of the ILO is fundamental in the assessment of unstable employment. It takes into account contractual arrangements and precarious working conditions. The ILO to unstable contractual agreements include limited duration of the contract (fixedterm contract, short-term contract, temporary, seasonal, filed and casual work), terms and conditions of employment relationships (multilateral and covert employment relationships, fictitious (false) self-employment, subcontracting and agency contracts). The ILO refers to precarious working conditions as low wages, poor protection against termination of employment, lack of access to social protection and benefits (traditionally associated with standard employment) and lack or limitation of access for workers to exercise their rights in the workplace.

An important problem in the study of precarious is its measurement and evaluation. A. Kalberg notes that the diversity of manifestations of precarious leads to the fact that it is difficult to distinguish it as a statistically measurable unit (Kalleberg \& Hewison, 2013). For this reason, the study of precarious suggests various aspects of its measurement.
These are temporary aspects (connected with continuity of work), organization aspects (control over work and its planning, working conditions), economic aspects (remuneration) and social aspects (degree of protection) (Rodgers \& Rodgers, 1989). The level of precariousness employment can be estimated based on vulnerable employment as a share of vulnerable employment in total number of employment. The simplicity of such an assessment is that quantitative methods can be assessed based on the ILO methodology (for determining selfemployment). It is important to note that self-employed persons, which belong to vulnerable employment. They do not use hired labor and unpaid workers of the family enterprises and households.

In Kazakhstan, the number of self-employed determines by a sample population survey. In particular, the statistical form of the state statistical observation "questionnaire of the sample survey of employment of the population" is used. Population survey carries out by interviewing method, by direct visiting of households by interviewers. The statistical form fills in for each individual household in the sample. The precariousness of employment can be assessed based on the vulnerable employment and unemployment. In various studies, precarious work in the labor market considered taking into account the unemployment (Bobkov, 2012). This makes sense because the unemployed cannot be considered more secure or stable than, for example, selfemployed persons. This method is more representative of the labor force as a whole, which is in a state of instability. For such an assessment of the level of precariousness, it is necessary to bring two indicators vulnerable employment and unemployment to one denominator - the labor force. Exactly, the unemployment rate is measured in the composition of the labor force.

The level of precariousness can be calculated by measuring employment in the informal economy. Thus, the ILO calculates three indicators for the informal economy: the share of informal employment, the share of workers in the informal sector and the share of informal employment outside the informal sector. The key criteria for determining the informal sector is the state registration of the organization. Thus, precariousness of employment is multidimensional, which is to evaluate by using different methods and indicators. With account the difficulty of obtaining a quantitative assessment of the precariousness employment can be carried out based on factor analysis (Fedorova, 2015). In our view, for a better understanding, it is necessary to clarify what is the impact of each factor or through which channels and means this effect occurs (Table $1)$. 
Table 1. Factors of the precariousness employment

\begin{tabular}{|c|c|c|}
\hline Factors & Channels and Tools & Forms of manifestation \\
\hline \multicolumn{3}{|l|}{ Global / International } \\
\hline \multirow[t]{3}{*}{ Transnationalization } & Direct foreign investments & $\begin{array}{l}\text { Flexibility of enterprises. Moving jobs abroad. Attraction of foreign labor. } \\
\text { Outsourcing. }\end{array}$ \\
\hline & Migration of labor & $\begin{array}{l}\text { Legal and illegal labor migration. Seasonal employment. Employment in } \\
\text { dangerous, heavy work. Quotas for attracting foreign labor. }\end{array}$ \\
\hline & Market liberalization & $\begin{array}{l}\text { Deregulation and competition. Flexible employment. Precarious work. Long-term } \\
\text { unemployment. }\end{array}$ \\
\hline \multirow[t]{3}{*}{ Technologies } & Structural shifts & $\begin{array}{l}\text { Growth of employment in the service sector. Services } 24 / 7 \text {, call-centers. Remote } \\
\text { employment. }\end{array}$ \\
\hline & ICT development & Labor mobility. Work "without a job". Remote employment. Flexible employment. \\
\hline & Automation & Underemployment \\
\hline \multicolumn{3}{|c|}{ Country/regional factors } \\
\hline Institution factors & $\begin{array}{l}\text { Laws and international labor } \\
\text { agreements. }\end{array}$ & $\begin{array}{l}\text { Deregulation. Employment based on fixed-term contracts. Decrease in job } \\
\text { security. Flexible labor market. Work migration. Quotas for attracting foreign labor }\end{array}$ \\
\hline Structure factors & $\begin{array}{l}\text { Growth and decline of } \\
\text { industries, new industries, } \\
\text { services }\end{array}$ & $\begin{array}{l}\text { Structural unemployment. New work place. New qualification requirements. } \\
\text { Labor mobility. Labor migration. } \\
\text { Retraining }\end{array}$ \\
\hline Demography & $\begin{array}{l}\text { Population structure, } \\
\text { migration }\end{array}$ & $\begin{array}{l}\text { Inequality. Women, youth, rural unemployment. } \\
\text { Part-time work. Unpaid internships for young people. }\end{array}$ \\
\hline Social & Income & $\begin{array}{l}\text { Productive and unproductive employment. The working poor. Income inequality. } \\
\text { Work migration. Vulnerable employment. }\end{array}$ \\
\hline \multicolumn{3}{|l|}{ Branded factors } \\
\hline Employer & Labor contracts & $\begin{array}{l}\text { Agency work. Part-time employment; contract work, etc. Flexible employment. } \\
\text { Split labor relations }\end{array}$ \\
\hline \multicolumn{3}{|l|}{ Individual factors } \\
\hline Employee & Individual perception & $\begin{array}{l}\text { Voluntary and forced precariousness. Freelancers. Self-employed. Informal } \\
\text { employment. Flexible employment. }\end{array}$ \\
\hline
\end{tabular}

In the study of employment precariousness in the EAEU countries, we decided to use two groups of factors - global and country factors of precariousness.

\section{Results and Discussion}

The analysis presents the main social and economic indicators of the EAEU countries for the period 2012-2016. This analysis shows that in most of the EAEU countries of associations there is a general normalization of the main indicators on the labor market. At the same time, the problem of precariousness of employment in the EAEU countries remains quite acute. For a more generalized characteristic of precariousness of employment, it is necessary to identify a number of criteria for classifying the forms of precarious employment in order to measure and estimate it. We propose the following 16 criteria and specific features of the classification of forms of precarious employment (Table 2).

The basis of this classification takes into account the approaches that use the ILO, the EU, the OECD, the Committee on Statistics MNE RK, including methodological explanations for the study of the economic activity of the population, methods for determining the number of selfemployed, migration of the population and evaluation of the shadow economy. We carried out an assessment of employment precariousness in the EAEU countries taking into account the proposed classification and precarious factors.

Globalization. Since the early 1990s, the EAEU countries have involved to varying degrees in globalization processes: foreign investment has attracted, migration processes have intensified, and labor mobility has increased. Russia and Belarus have the highest level of globalization, which is due to a higher level of social globalization in terms of such indicators as cultural intimacy. While Kazakhstan and Kyrgyzstan had a higher level of attracting foreign investment relative to GDP - 13,2\% and 7,1\% respectively.

Demography. The EAEU countries have different demographic trends. In Kazakhstan and Kyrgyzstan, there is an increase in the population, labor force. In particular, Kazakhstan has overcome the consequences of the 1990s due to the decline in fertility and external migration. This has resulted in a reduction of almost 2 million people. Now, the population of Kazakhstan has exceeded 18 million people. In Russia, Belarus and Armenia, there has been a decline in 
Table 2. The classification of forms of precarious employment

\begin{tabular}{|c|c|c|}
\hline No. & Criteria & Forms of precarious employment \\
\hline 1 & $\begin{array}{l}\text { Based on the reasons and } \\
\text { conditions }\end{array}$ & Voluntary. Forced. \\
\hline 2 & $\begin{array}{l}\text { By duration and terms of } \\
\text { agreements }\end{array}$ & $\begin{array}{l}\text { Contract for a fixed period. Short-term employment contracts. Temporary, seasonal, day-work } \\
\text { and casual labor. Part-time employment. Forced part-time work (less than } 30 \text { hours per week). }\end{array}$ \\
\hline 3 & Under the terms of the contracts & $\begin{array}{l}\text { Multilateral and hidden employment relationships. } \\
\text { Explicit, implicit, written oral agreements }\end{array}$ \\
\hline 4 & By nature of income & $\begin{array}{l}\text { Unproductive employment. Productive employment. Low salary. Flexible salary. Legal income. } \\
\text { Illegal income. }\end{array}$ \\
\hline 5 & By the degree of labor autonomy & $\begin{array}{l}\text { Dependent employees. Independent workers (freelancers). Quasi-dependent employment, self- } \\
\text { employment (outsourcing, out staffing, leasing). Hired entrepreneurship. }\end{array}$ \\
\hline 6 & By the level of formality & $\begin{array}{l}\text { Informal employment in the formal sector. Formal employment in the informal sector. Informal } \\
\text { employment in the informal sector. }\end{array}$ \\
\hline 7 & By the level of openness & $\begin{array}{l}\text { Open, recorded precarious employment. Shadow employment, employment of illegal labor } \\
\text { migrants. Hidden precariousness (latent). }\end{array}$ \\
\hline 8 & By the level of vulnerability & $\begin{array}{l}\text { Self-employed, not using hired labor. Unpaid workers of family enterprises and households. } \\
\text { Working poor. }\end{array}$ \\
\hline 9 & $\begin{array}{l}\text { According to the conditions of } \\
\text { qualification growth }\end{array}$ & $\begin{array}{l}\text { Work is not in the specialty obtained because of training. Lack of conditions for professional } \\
\text { development. The lack of connection between the growth of skills and wages. }\end{array}$ \\
\hline 10 & In terms of flexibility & $\begin{array}{l}\text { Functional flexibility. Quantitative flexibility. } \\
\text { Temporary flexibility. Financial Flexibility }\end{array}$ \\
\hline 11 & On the level of stability & $\begin{array}{l}\text { Stable precariousness; unstable precarious (transition from one employer to another); } \\
\text { transitional pre-occupation of employment }\end{array}$ \\
\hline 12 & By regularity & Seasonal. Casual employment. Temporary employment. Additional employment (second job). \\
\hline 13 & By severity, danger & Work in adverse or dangerous conditions. "3D jobs". Work of high intensity. \\
\hline 14 & In relation to the workplace & Remote employment. Lack of a workplace. Workplace outside the employer's location. \\
\hline 15 & On the quality of employment & Employment that does not meet the principles of decent work \\
\hline 16 & On the level of social protection & $\begin{array}{l}\text { Unstable labor agreements that do not contain social responsibility } \\
\text { Unstable labor agreements containing social responsibility. }\end{array}$ \\
\hline
\end{tabular}

three categories: the population as a whole, the population aged 0-14 years and the workforce (Table 3 ).

Generally, the expected reduction of population in Russia to the level of 120 million people, and in Belarus up to 7 million people. The situation in the field of demography determines the conditions for migration. Therefore, migration in Russia and Belarus will remain an important source of replenishment of the labor force. Thus, both countries will experience a greater impact of external labor migration compared to other countries of the EAEU.

Table 3. Dynamics of population and labor force in the EAEU countries in $2016 / 1990$

\begin{tabular}{|c|c|c|c|}
\hline & $\begin{array}{c}\text { Labor force, } \\
\mathbf{2 0 1 6} \text { to } 1990 \\
\text { (\%) }\end{array}$ & $\begin{array}{c}\text { Population, } \\
\mathbf{2 0 1 6} \text { to } \mathbf{1 9 9 0} \\
\text { (\%) }\end{array}$ & $\begin{array}{c}\text { Population } \\
\text { aged 0-14 } \\
\text { years, 2016 to } \\
\mathbf{1 9 9 0} \text { (\%) }\end{array}$ \\
\hline Armenia & 99,9 & 82,7 & 54,8 \\
\hline Belarus & 91,1 & 93,3 & 67 \\
\hline Kazakhstan & 118 & 108,9 & 94,9 \\
\hline Kyrgyzstan & 144,9 & 138,5 & 116,6 \\
\hline Russia & 98,5 & 97,3 & 73,5 \\
\hline
\end{tabular}

Source: World Development Indicators
Migration. In the EAEU countries, migration is solved problems in the field of employment. More than $50 \%$ of migration flows are formed between the EAEU countries. In the framework of the EAEU, Kazakhstan and Russia are the largest donors of the labor force. They account for $89 \%$ of migration flows to the EAEU. Armenia and Kazakhstan have the highest outflow in the accumulated migration. At the same time, Kazakhstan, unlike Armenia, managed to create conditions for the inflow of a significant volume of migrants, in that force and at the expense of returnees. In 2015, the EAEU countries, except Russia, had a negative balance of accumulated external migration. The positive balance of Russia is formed due to the migration flow from the EAEU countries (Table 4).

Russia is one of the largest countries receiving migrant workers according to research by the International organization for migration (IOM) along with USA and Canada. More than $70 \%$ of labor migrants in Russia are residents of the EAEU and the CIS countries. In Russia, 38\% of migrants come from the EAEU countries and $38 \%$ from Ukraine (3270,0 thousand persons) and Uzbekistan (1146, 8 thousand persons). Many forms of precariously employed workers are linked with labor and illegal migration. In 2015, 
$20 \%$ of foreigners were engaged in legitimate work in Russia (Shatilov \& Galas, 2017). The high level of precariousness among migrant workers is a global trend. It is possible to form an idea of the prevalence of unstable employment within countries, which makes migration to be considered as a more attractive alternative based on the scale of labor migration and personal money transfers (Table 5).

Table 4. Cumulative migration in the countries of the EAEU in 2015

\begin{tabular}{|l|c|c|c|c|c|}
\hline \multirow{2}{*}{} & \multicolumn{3}{|c|}{ Emigrated from, thousands of people } \\
\cline { 2 - 5 } & Armenia & Belarus & Kazakhstan & Kyrgyzstan & Russia \\
\hline Armenia & & 0,3 & 0,8 & 0 & 20,6 \\
\hline Belarus & 5,7 & & 70,0 & 5,2 & 682,3 \\
\hline Kazakhstan & 9,1 & 69,1 & & 6,7 & 2352,6 \\
\hline Kyrgyzstan & 1,7 & 9,9 & 12,9 & 111,8 \\
\hline Russia & 527,3 & 764,3 & 2560,3 & 591,4 & \\
\hline In the EAEU countries & 543,8 & 843,7 & 2644,0 & 603,3 & 3167,3 \\
\hline Total to countries of the world & 937,3 & 1485,3 & 4075,7 & 760,8 & 10576,1 \\
\hline Migrants from the countries of the EAEU, thousands of people & 21,8 & 763,3 & 2437,6 & 136,3 & 4443,2 \\
\hline Migrants, thousands of people & 191,2 & 1082,9 & 3546,8 & 204,4 & 11643,3 \\
\hline The proportion of migrants from the countries of the EAEU, \% & $11,4 \%$ & $70,5 \%$ & $68,7 \%$ & $65,9 \%$ & $38,2 \%$ \\
\hline The share of migrants in total, \% from the total population & $6,3 \%$ & $11,4 \%$ & $20,1 \%$ & $3,4 \%$ & $8,1 \%$ \\
\hline Lives outside the country, in \% from the population & $23,7 \%$ & $13,5 \%$ & $18,9 \%$ & $11,4 \%$ & $6,9 \%$ \\
\hline Migration balance, thousands of people & $-746,1$ & $-402,4$ & -529 & $-556,5$ & 1067,2 \\
\hline Migration balance within of the EAEU, thousands of people & $-522,1$ & $-80,4$ & $-206,4$ & -467 & 1275,9 \\
\hline
\end{tabular}

Source: (IOM, 2017)

Table 5. Personal remittances in the EAEU countries and groups of countries

\begin{tabular}{|c|c|c|c|c|c|c|}
\hline Country, groups of countries & 1995 & 2000 & 2005 & 2010 & 2015 & 2016 \\
\hline & \multicolumn{6}{|c|}{ Personal remittances received, $\%$ of GDP } \\
\hline High-income countries & 0,2 & 0,2 & 0,2 & 0,3 & 0,3 & 0,3 \\
\hline Middle-income countries & 1,1 & 1,6 & 1,8 & 1,4 & 1,5 & 1,5 \\
\hline Low-income countries & 2,8 & 4,1 & 4,9 & 4,3 & 4,5 & 4,1 \\
\hline Armenia & 4,9 & 9,5 & 18,7 & 18,0 & 14,2 & 13,1 \\
\hline Belarus & 0,2 & 0,9 & 0,7 & 1,0 & 1,6 & 2,0 \\
\hline Kazakhstan & 0,6 & 0,4 & 0,1 & 0,2 & 0,1 & 0,2 \\
\hline Kyrgyzstan & 0,1 & 0,2 & 12,7 & 26,4 & 25,3 & 30,4 \\
\hline \multirow[t]{2}{*}{ Russia } & 0,0 & 0,2 & 0,4 & 0,3 & 0,5 & 0,5 \\
\hline & \multicolumn{6}{|c|}{ Personal remittances, paid (current US\$) } \\
\hline Armenia & & 3,5 & 207,4 & 227,4 & 363,8 & 358,0 \\
\hline Belarus & 11,9 & 9,6 & 52,2 & 115,7 & 162,3 & 123,8 \\
\hline Kazakhstan & 6,6 & 121,4 & 1893,1 & 3005,8 & 3116,5 & 2394,5 \\
\hline Kyrgyzstan & 9,8 & 11,2 & 53,3 & 167,7 & 362,6 & 377,6 \\
\hline \multirow[t]{2}{*}{ Russia } & 468,7 & 232,2 & 6827,2 & 21454,0 & 19688,8 & 16590,3 \\
\hline & \multicolumn{6}{|c|}{ Personal remittances, received (current US\$) } \\
\hline Armenia & 71 & 182 & 915 & 1669 & 1491 & 1382 \\
\hline Belarus & 29 & 114 & 199 & 575 & 932 & 961 \\
\hline Kazakhstan & 116 & 67 & 62 & 226 & 194 & 275 \\
\hline Kyrgyzstan & 1 & 2 & 313 & 1266 & 1688 & 1995 \\
\hline \multirow[t]{2}{*}{ Russia } & 166 & 500 & 3437 & 5250 & 6903 & 6678 \\
\hline & \multicolumn{6}{|c|}{ Personal remittances, balance, mln. US\$ } \\
\hline Armenia & & 179 & 708 & 1442 & 1128 & 1024 \\
\hline Belarus & 17 & 105 & 146 & 460 & 769 & 838 \\
\hline Kazakhstan & 109 & -54 & -1831 & -2780 & -2922 & -2119 \\
\hline Kyrgyzstan & -9 & -9 & 260 & 1098 & 1325 & 1617 \\
\hline Russia & -303 & 268 & -3391 & -16204 & -12785 & -9912 \\
\hline
\end{tabular}

Source: World Development Indicators 
Armenia (13,1\% of GDP) and Kyrgyzstan ( $31,4 \%$ of GDP) have the highest level in terms of personal remittances. This indicates the large scale of labor migration, as well as the fact that in Armenia and Kyrgyzstan, the incomes of the population and the maintenance of living standards depend heavily on the opportunity to find work outside the country. This situation demonstrates a high level of the precariousness employment. In terms of personal remittances, Kyrgyzstan and Armenia are at a much higher level than middle-income and low-income countries.

In 2010, the EAEU countries signed an Agreement on cooperation to combat illegal labor migration from third countries (EEC, 2010). On 1 January 2015, the agreement on the Eurasian Economic Union entered into force. According to this agreement, the stage of free movement of capital, goods, services and labor within the EAEU begins (EAEU, 2015). The agreement on the Eurasian Economic Union established equal rights for the citizens of the EAEU in the labor market and employment, which reduced the motives for illegal migration and the opportunity to apply discriminatory measures against migrants. A significant number of migrants from Ukraine and Tajikistan remain outside the agreement's influence. In the section, XXVI "Labor migration" of the agreement on the EAEU provides for the following conditions: increased terms of temporary stay in the territory and excluded the requirements for obtaining a work permit, which are applied to foreign labor force to protect the domestic market, social security of migrants and accounting for length of service for social security. Labor migrants from the EAEU countries have the right to receive medical care and medical services. The legislation of the countries of residence regulates pension provision. These measures are aimed at ensuring security and reducing precariousness in the field of labor migration. In addition, many factors of the precariousness employment lie outside the influence of this agreement and are due to internal processes in the EAEU countries.

Structure factor. The scale of the spread of unsustainable employment is largely due to the structural features of the EAEU countries. Structural features of the countries determine the degree of resistance to cyclic fluctuations. The decline in commodity prices, reduced investment, weak external demand, and the decline in solvency because of the devaluation of the national currency had a negative impact on the economic growth of the EAEU countries and employment. The structure of the economies of the EAEU countries has significant differences. Armenia and Kyrgyzstan have a high share of agriculture and high rural employment (up to 30\%). Since 1991-2016, the share of agriculture in Kazakhstan has decreased six times in GDP, but the share of the rural population and employment in agriculture remains high. In the EAEU countries, the most developed is industrial sector. Especially manufacturing in Belarus and Kyrgyzstan. Russia and Kazakhstan have a developed extractive industry and the service sector is faster here than in other EAEU countries. Overall, the structure of GDP is changing: the share of services is increasing and the share of agriculture is declining. A similar trend is observed in the rest of the world (Table 6).

Table 6. The structure of GDP, employment, population growth in the EAEU countries for 2016, \%

\begin{tabular}{|c|c|c|c|c|c|}
\hline & Armenia & Belarus & Kazakhstan & Kyrgyzstan & Russia \\
\hline $\begin{array}{c}\text { Agriculture } \\
\text { Value added } \\
\text { (\% of GDP) }\end{array}$ & 19 & 7 & 5 & 16 & 5 \\
\hline $\begin{array}{c}\text { Agriculture The } \\
\text { share of } \\
\text { employment, \% }\end{array}$ & 35 & 10 & 18 & 29 & 7 \\
\hline $\begin{array}{c}\text { Industry Value } \\
\text { added } \\
\text { (\% of GDP) }\end{array}$ & 29 & 38 & 33 & 28 & 33 \\
\hline $\begin{array}{c}\text { Services The } \\
\text { share of } \\
\text { employment, \% }\end{array}$ & 16 & 31 & 21 & 21 & 27 \\
\hline $\begin{array}{c}\text { Urban } \\
\text { population } \\
\text { growth } \\
\text { (annual \%) }\end{array}$ & 0,1 & 0,7 & 1,4 & 2,5 & 0,3 \\
\hline $\begin{array}{c}\text { Rural } \\
\text { population } \\
\text { growth } \\
\text { (annual \%) }\end{array}$ & 0,6 & $-1,5$ & 1,5 & 1,9 & $-0,2$ \\
\hline
\end{tabular}

Source: World Development Indicators

The EAEU countries can be classified as highly urbanized countries in terms of urbanization (urban population accounts for more than $50 \%$ of the population). Urbanization rates in Russia and Belarus are the highest among the CIS countries the share of residents of urban settlements is $74 \%$ and $76 \%$, Armenia $-62 \%$, in Kazakhstan - 53,2\%, Kyrgyzstan - 35,9\%. At the same time, urban population growth is faster in Kazakhstan $(1,4 \%)$ and Kyrgyzstan $(2,5 \%)$. Armenia, Kyrgyzstan and Kazakhstan have a high share of employment in agriculture, which has an impact on unemployment, self-employment and precariousness.

Shadow economy. In this research, there is a proof of the relationship between the precariousness employment and the shadow economy. Workers in the informal sector are covered by employment contracts and are not protected by legal protection mechanisms. This process mainly affected developing countries and countries with economies in transition. Experts give different estimates of the size of the shadow economy in the EAEU countries. According to national statistical offices, the share of non-observed economy in Kazakhstan is 25, $8 \%$, in Kyrgyzstan - 23, 8\% (CS of MNE RK, 2017; NSC of KR, 2017). According to 
estimates (Medina \& Schneider, 2017) the share of the shadow sector in the EAEU countries exceeds $40 \%$. The desire to evade taxes gave rise to a new phenomenon in the economy as one-day firms. In the Post-Soviet space, this problem represented in Russia. In total, commercial organizations registered in the tax system of Russia - 3,9 million firms. Actually making payments through the banking system about 2 million firms (which makes payments through the banking system). Nevertheless, there are $11 \%$ organizations, which do not pay any taxes and another 4-6\% of organizations, which pay purely symbolic amounts (Ignatiev, 2013). Such organizations hide the staff of workers who are classified as informal workers, but no contracts have been concluded with them.

Informal sector. Informal employment is seen as one of the forms precariousness employment and difficult for calculation. The results depend on the interpretation of the boundaries between formal and informal employment, illegal employment and economic inactivity, informal employment and the shadow economy. Informal employment, along with other labor market distortions, is an obstacle to economic growth and modernization in the EEA economies. In the informal sector and the precariousness employment are involved from 20\% (Russia, Kazakhstan), 47\% (Armenia) to $70 \%$ (Kyrgyzstan) of the employed population in the EAEU

Social development and standard of living. A standard of living and the income structure in the EAEU countries are different. In 2015, money incomes per capita per month in the EAEU countries were US\$ 63 in Kyrgyzstan, US\$ 110 in Armenia, US\$ 303 in Kazakhstan, US\$ 304 in Belarus, US\$ 498 in Russia (Table 7).

Table 7. Living standards of the population in the Eurasian Economic Union

\begin{tabular}{|c|c|c|c|c|c|}
\hline Indicator & Armenia & Belarus & Kazakhstan & Kyrgyzstan & Russia \\
\hline $\begin{array}{c}\text { Monetary } \\
\text { income per } \\
\text { capita per } \\
\text { month, US\$ }\end{array}$ & 110 & 304 & 303 & 63 & 498 \\
\hline $\begin{array}{c}\text { Average } \\
\text { monthly } \\
\text { nominal wage, } \\
\text { US\$ }\end{array}$ & 359 & 413 & 568 & 209 & 561 \\
\hline $\begin{array}{c}\text { Minimum wage, } \\
\text { US\$ }\end{array}$ & 114 & 121 & 66 & 13 & 86 \\
\hline $\begin{array}{c}\text { Average size of } \\
\text { pension, US\$ }\end{array}$ & 85 & 156 & 121 & 65 & 158 \\
\hline $\begin{array}{c}\text { Minimal amount } \\
\text { of pension, } \\
\text { US\$ }\end{array}$ & 33 & 116 & 73 & 20 & 63 \\
\hline $\begin{array}{c}\text { The number of } \\
\text { pensioners per } \\
1000 \text { person of } \\
\text { the population }\end{array}$ & 155 & 273 & 112 & 107 & 292 \\
\hline
\end{tabular}

\begin{tabular}{|c|c|c|c|c|c|}
\hline \begin{tabular}{|c|} 
Minimum \\
subsistence per \\
month in per \\
capita terms
\end{tabular} & No data & 88 & 61 & 65 & 136 \\
\hline $\begin{array}{l}\text { Minimum wage } \\
\text { in } \% \text { of the } \\
\text { subsistence } \\
\text { minimum of the } \\
\text { able-bodied } \\
\text { population }\end{array}$ & No data & 124,5 & 90,8 & 17,6 & 58,6 \\
\hline $\begin{array}{c}\text { Level of } \\
\text { poverty, in \% }\end{array}$ & 29,8 & 5,1 & 2,7 & 32,1 & 13,3 \\
\hline \begin{tabular}{|c|} 
Coefficient of \\
funds (on 10 \\
percent groups \\
of the \\
population)
\end{tabular} & 16,4 & 6,1 & 5,6 & 11,8 & 15,6 \\
\hline
\end{tabular}

\section{Source: (EEC, 2016a)}

The minimum wage in the EAEU countries, with the exception of Belarus, is below the subsistence minimum. The minimum wage in Kyrgyzstan is $17 \%$, in Russia - $58 \%$ and Kazakhstan - 90\%. Almost $30 \%$ of the population of Armenia and Kyrgyzstan are in poverty.

Unemployment rate. In the EAEU countries, there is a different level of unemployment and self-employment Official statistical data of the EAEU countries on the unemployment rate demonstrate comparative stability in the labor market. At the beginning of 2016, unemployment in the EAEU countries averaged about 9\% (EEC, 2016 b). However, a high level of unemployment remains in Armenia and Kyrgyzstan. In Belarus, the unemployment rate is low, but there is a problem of hidden unemployment.

Vulnerable employment. Now, the most vulnerable to the problem of precariousness of employment is the data on vulnerable employment. In the EAEU countries, a different structure of vulnerable employment can be noted. If in Belarus (93,7\%), Russia $(93,1 \%)$ and Kazakhstan $(99,6 \%)$ the bulk of self-employment is formed mainly at the expense of the own-account workers. Then in Armenia (28,9\%) and Kyrgyzstan $(26,3 \%)$ a very large proportion of contributing family workers. This suggests that the point of view of the quality of self-employment in Armenia and Kyrgyzstan the problem of precariousness is more important than in other countries of the EAEU (Table 8). Armenia and Kyrgyzstan have the highest precariousness level in the labor force (vulnerable employment with account unemployment more than 40\%). In Kazakhstan, this indicator is also high (about 30\%). 
Table 8. Unemployment and vulnerable employment in the EAEU countries

\begin{tabular}{|l|c|c|c|c|}
\hline \multicolumn{1}{|c|}{ Country } & $\mathbf{2 0 0 0}$ & $\mathbf{2 0 0 5}$ & $\mathbf{2 0 1 0}$ & $\mathbf{2 0 1 6}$ \\
\hline Vulnerable employment share of total employment, \% \\
\hline Armenia & 38,7 & 39,4 & 42,0 & 40,3 \\
\hline Belarus & 2,5 & 2,4 & 2,6 & 2,6 \\
\hline Kazakhstan & 38,5 & 35,3 & 31,1 & 25,1 \\
\hline Kyrgyzstan & 54,7 & 48,7 & 38,1 & 36,6 \\
\hline Russia & 7,9 & 6,3 & 5,6 & 6,2 \\
\hline Unemployment, total (\% of total labor force) \\
\hline Armenia & 10,9 & 8,2 & 19,0 & 17,6 \\
\hline Belarus & 2,1 & 1,5 & 1,1 & 5,8 \\
\hline Kazakhstan & 3,7 & 8,1 & 5,8 & 5,0 \\
\hline Kyrgyzstan & 7,5 & 8,1 & 8,6 & 7,2 \\
\hline Russia & 10,6 & 7,1 & 7,4 & 5,5 \\
\hline Vulnerable employment share of labor force, \% \\
\hline Armenia & 31,7 & 32,6 & 34,0 & 33,6 \\
\hline Belarus & 2,5 & 2,4 & 2,6 & 2,6 \\
\hline Kazakhstan & 33,5 & 32,4 & 29,3 & 23,6 \\
\hline Kyrgyzstan & 50,6 & 44,7 & 34,8 & 33,9 \\
\hline Russia & 7,1 & 5,8 & 5,2 & 6,4 \\
\hline Vulnerable employment in the EAEU, share of labor force, \% \\
\hline $\begin{array}{l}\text { Labor force of the EAEU, } \\
\text { total thousand people }\end{array}$ & 88365 & 91762 & 94069 & 94443 \\
\hline $\begin{array}{l}\text { Vulnerable employment in } \\
\text { the EAEU, thousand } \\
\text { people }\end{array}$ & 9245 & 8564 & 7986 & 8516 \\
\hline $\begin{array}{l}\text { Vulnerable employment } \\
\text { share of labor force, \% }\end{array}$ & 10,5 & 9,3 & 8,5 & 9,0 \\
\hline
\end{tabular}

These data reflect part of the problem of precariously employed without regard to precariously employed formal sector employment and hidden forms of precariousness. However, the level of precariousness will be higher taking into account informal employment, insecure and nonstandard forms of employment in the formal sector. In Armenia and Kyrgyzstan, the level of precariousness employment in terms of the proportion of self-employed among the employed population is $40 \%$. This creates great problems and risks for the social and pension systems of these countries, the reproduction of labor potential through increased migration. It should be noted that the unemployment rate exceeding $10 \%$ according to world criteria is considered dangerous. Nevertheless, with the possible decrease in unemployment rates, the share of selfemployment in the EAEU countries remains high in Armenia Kazakhstan and Kyrgyzstan.

Thus, the precarious employment in the countries of the EAEU is multifactorial and multidimensional. The influence of factors has different effects on the depth and extent of precarious. In Armenia, the precarious employment associated due to the high level of unemployment and vulnerable employment. In Kazakhstan and Kyrgyzstan, the precarious employment associated with structure features and a high share of rural employment, in Belarus demographic characteristics, in Russia - the level of migration, demographic trends. In addition, institutional systems in all countries are not yet well adapted to the challenges of precarious.

\section{Conclusions}

The structure of labor market institutions, which has formed in the market economy, cannot respond to the challenges of precariousness employment and the complex problems of precarious. Thus, labor market institutions and other social guarantees in the sphere of labor relations have not formed. This process preceded by reflection in society problems, difficult periods of social struggle and institutional changes. The comprehension of this problems leads to the understanding that we should expect major transformations of institutions in the field of employment and labor market in the framework of the EAEU, and in each of the countries. The study of possible manifestations of precarious is important for overcoming the negative consequences. In this regard, we propose the following specific features of the classification of forms of precariousness employment: the duration and timing of agreements, under the terms of contracts and by the nature of income; the degree of labor autonomy; the level of formality; the level of openness; the level of vulnerability; the conditions of growth of qualification; the level of flexibility; the level of stability; regularity; severity danger of work; in relation to the workplace; the quality of employment and the level of social security. The study of the problems of precarious in accordance with the selected factors led to the conclusion that the precariousness employment in the EAEU countries is a multi-factor and multidimensional phenomenon. In each country the influence of factors having a different influence on the depth and scope of precarious. The EAEU countries have been involved in globalization processes to varying degrees. There are different demographic trends in the EAEU countries.

Kazakhstan and Kyrgyzstan demonstrated growth in population and labor force. While in Russia, Belarus and Armenia showed a decline in the population as a whole, the population aged 0-14 years and the workforce. The demographic situation determines the conditions for migration, including labor migration. The high level of labor migration poses great risks to the social and pension systems of these countries in the future. In Russia, taking into account the declining trend in fertility, migration will be the main source of replenishment of the workforce, which creates risks of rising precariousness, which are caused by 
illegal labor migration. The agreement on the Eurasian Economic Union has changed the conditions for labor migration, established equal rights of citizens in the labor market and employment, and reduced the motives for illegal migration and the ability to apply discriminatory measures against migrants. This situation is aimed at reducing precariousness, especially due to labor migration.

It should be noted that the EAEU countries have a different structure of vulnerable employment. Thus, in Belarus, Russia and Kazakhstan, the self-employment form on an individual basis. In turn, in Armenia and Kyrgyzstan, family household workers form the self-employed. This suggests that the quality of self-employment and the problem of precarious is much more acute in Armenia and Kyrgyzstan than in other EAEU countries. Thus, Armenia and Kyrgyzstan have the highest level of precariat in the labor force. In Kazakhstan, the level of precariousness is highly - about $30 \%$. The precariousness employment in these three countries is associated mainly with the solution of structured problems: with the growth and diversification of industrial production, increase of efficiency of agriculture and reducing rural employment, increase labor mobility within countries.

\section{References}

Atkinson, J. (1984). New patterns of working relationships. Education + Training, 26(10), 318-320.

Autor, D. H., \& Houseman, S. (2010). Do Temporary-Help Jobs Improve Labor Market Outcomes for LowSkilled Workers? Evidence from "Work First". American Economic Journal: Applied Economics, 2(3), 96-128.

Bobkov, V. (2012). 20 years of capitalist transformation in Russia: Impact on the level and quality of life. Universe of Russia, 21(2), 3-26.

Bobkov, V., Novikova, I., \& Odintsova, Y. (2017). Identifying the profile of precarious employment in Russia. Level of Life of the Population of Region of Russia, 4(206 ), 26-35.

Bourdieu, P. (1998). Acts of Resistance. Against the New Myths of our Time. Cambridge: Polity Press and The New Press.

CS of MNE RK (2017). Integrated accounts. Share of the non-observed economy in GDP. Retrieved 20.12.2017 from www.stat.gov.kz/faces/wcnav externalld/homeNationalAccountIntegrated

EAEU (2015). Treaty on the Eurasian Economic Union. Retrieved 20.12.2017 from www.eaeunion.org

EEC (2010). Agreement on Cooperation in Counteracting Illegal Labour Migration from Third Countries.
Retrieved

20.12.2017

from

www.eurasiancommission.org

EEC $(2016$ b). Express information of the Special Commission on Unemployment at the EAPC, February 29, 2016. Retrieved 20.12.2017 from www.eurasiancommission.org.

EEC (12 2016a г.). On the population's living standard in the Eurasian Economic Union in 2015. Retrieved 20.12.2017 www.eurasiancommission.org

EU (2013). Priorities for occupational safety and health research in Europe: 2013-2020. Luxembourg: European Community.

Fedorova, N. (2015). Methodological Approaches to the Study of Employment Precarisation. Knowledge. Understanding. Skill, 6(November-Desember), 70-78. Retrieved 20.12.2017 from www.zpu-journal.ru/ezpu/2015/6/Fedorova_Employment-Precarisation

Friedman, M. (1978). Inflation and Unemployment: The New Dimension of Politics. London: Institute of Economic Affairs.

Gasyukova, Y. (2015). Prekarizatsiya: kontseptual'nyye osnovaniya, faktory i otsenki. Outlines of Global Transformations: Politics, Economics, Law, 8(6(44)), 28-46

Ignatiev, S. (2013, 02 02). Illegal operations reduce the budget by 600 billion rubles a year. Retrieved 20.12.2017 from https://ria.ru/economy/20130220/ 923783584.html

ILO (2016). Non-standard employment around the world: Understanding challenges, shaping prospects. Geneva

IOM (2017). Global Migration Flows. Retrieved 20.10.2017 from www.iom.int: http://www.iom.int/world-migration

Jumambayev, S. (2016). The Precarization of Employment: A Case of Kazakhstan. The Journal of Asian Finance, Economics and Business, 3(2), 59-66.

Kalleberg, A. L., Hewison, K. (2013). Precarious Work and the Challenge for Asia. American Behavioral Scientist, 57(3), 271-288.

Keynes, J. (2010). General Theory Of Employment , Interest And Money. Kessinger Publishing, LLC.

Marx, K. (2001). Capital. A Critique of Political Economy (Vol. 1). Moscow: AST, 565 p.

Medina, L., \& Schneider, F. (2017). Shadow Economies around the World: New Results for 158 Countries over 1991-2015. CESifo Working Paper No.6430, 30 p.

NSC of KR. (2017). Unobserved (hidden and informal) economy. Retrieved 11.12.2017 from http://www.stat.kg/ru/statistics/nacionalnye-scheta/

Rodgers, G., \& Rodgers, J. (1989). Precarious jobs in la bour market regulation: The growth of atypical em ployment in Western Europe. Geneva, Switzerland: 
International Institute for Labour Studies.

Sennet, R. (2006). The Culture of the New Capitalism. New Haven, Conn.: Yale University Press.

Shatilov, A., \& Galas, M. (2017, 03 23). Labor migration to Russia: what awaits our country in the future.
Retrieved 15.10.2017 from www.km.ru: http://www.km.ru/print/798171

Smith, A. (2007). Whelth of Nations. Moscow, Eksmo.

Standing, G. (2011). The Precariat: The New Dangerous Class. London: Bloomsbury Academic.

\section{Abbreviations}

EAEU - Eurasian Economic Union

EEC - Eurasian Economic Commission

EU-OSHA - European Agency for Safety and Health at Work

SC of RA - Statistical yearbook of Armenia. Statistical Committee of the Republic of Armenia.

NSC of KR -National Statistical Committee of the Kyrgyz Republic

FSSS Federal State Statistics Service of Russia

CS of MNE RK - Committee on Statistics of the Ministry of National Economy of the Republic of Kazakhstan

IOM - International Organization for Migration

ILO - International Labour Organization 